\title{
High frequency of potentially pathogenic yeast species in goat's raw milk and creamed cheese in Southern Brazil
}

\author{
Alta frequência de leveduras potencialmente patogênicas no leite de cabra in natura \\ e no queijo de cabra cremoso no Sul do Brasil
}

\section{Andréia Spanamberg ${ }^{1}$, Jesus Pais Ramos ${ }^{2}$, Orílio Leoncini ${ }^{3}$, Sydney Hartz Alves ${ }^{4} \&$ Patrícia Valente $^{5}$}

\begin{abstract}
There are few reports concerning isolation, counting and identification of yeasts in goat's raw milk and derivates. The objective of this study was to evaluate the diversity of yeasts found in raw goat milk and goat creamed cheese collected in a Metropolitan area in Porto Alegre - Brazil. A simplified HMA (Heteroduplex Mobility Assay) of the 26S rDNA D1/D2 region was developed in order to rapidly confirm the identification of the isolates belonging to potentially pathogenic species. Yeasts were isolated from $59 \%$ of the samples. Fifty six strains were isolated and identified in the genera Bullera, Candida, Cryptococcus, Debaryomyces, Dekkera, Pichia, Rhodotorula, Sporodiobolus, Trichosporon, Yarrowia and Zygoascus. The average yeast count in raw milk was superior to $2 \log$ UFC.mL ${ }^{-1}$, while cheese count was superior to 3 log UFC.g-1 . Lipolytic activity was present in almost $92 \%$ of the isolates, while only $14 \%$ had proteolytic activity. Twelve potentially pathogenic ascomycetic isolates were identified by the conventional yeast identification methodology, and correspond to the species Candida parapsilosis, Candida tropicalis and Pichia guilliermondii. All of them had their identities confirmed by the simplified HMA assay. None of the isolates belonging to potentially pathogenic species were resistant to the antifungal agents tested. More studies are necessary to evaluate the real significance of the isolation of these clinically relevant yeasts.
\end{abstract}

Keywords: yeast identification, goat milk, goat cheese, HMA, Candida spp.

\section{RESUMO}

Existem poucos relatos sobre isolamento, contagem e identificação de leveduras no leite de cabra in natura e derivados. O objetivo desse estudo foi avaliar a diversidade de leveduras encontradas no leite de cabra cru e no queijo cremoso de cabra coletados na região metropolitana de Porto Alegre, Brasil. Foi desenvolvida a técnica de HMA (Heteroduplex Mobility Assay) simplificada da região 26S rDNA D1/D2 para confirmar rapidamente a identificação de isolados pertencentes às espécies potencialmente patogênicas. Leveduras foram isoladas em $59 \%$ das amostras. Cinquenta e seis leveduras foram isoladas e identificadas nos gêneros Bullera, Candida, Cryptococcus, Debaryomyces, Dekkera, Pichia, Rhodotorula, Sporodiobolus, Trichosporon, Yarrowia e Zygoascus. A contagem média de leveduras no leite de cabra foi superior a 2 log UFC.mL $L^{-1}$, enquanto que a contagem no queijo foi superior a $3 \log$ UFC.g ${ }^{-1}$. A atividade lipolítica esteve presente em $92 \%$ dos isolados, enquanto que apenas $14 \%$ tiveram atividade proteolítica. Doze isolados ascomicéticos potencialmente patogênicos foram identificados pela metodologia convencional de identificação de leveduras e correspondem às espécies Candida parapsilosis, Candida tropicalis e Pichia guilliermondii. Todos tiveram sua identificação confirmada pela técnica de HMA simplificada. Nenhum dos isolados potencialmente patogênicos foram resistentes aos antifúngicos testados. Mais estudos são necessários para avaliar o real significado do isolamento dessas leveduras clinicamente relevantes.

Descritores: identificação de leveduras, leite de cabra, queijo de cabra, HMA, Candida spp. 


\section{INTRODUCTION}

There are few reports concerning isolation, counting and identification of yeasts in raw goat milk and goat cheese. Yeasts represent an important component of the microflora of lactic products, being usually detected in large counts in milk and derivates due to their richness in proteins, lipids, sugars and organic acids. Besides this, they are capable of growing in substrates with high salt concentrations and low $\mathrm{pH}$ $[24,28]$. Thus they can cause biochemical alterations in food and public health concern [16].

Control of lactic products, in a general way, involves hygienic and sanitary cares that begin in milk production, through adequate milking practices. This fact is relevant because yeasts can be related to cases of mycotic mastitis in goats and cows $[10,20]$, being responsible for economic losses due to the reduction of milk production and augmentation of costs of the production [2,10]. The species of the genus Candida are the yeasts more commonly isolated from milk [36]. Some studies report the occurrence and growth of yeasts in several types of cheese and their subproducts [17,35], besides being related to the deterioration of yogurts, concentrated milk and pasteurized milk $[13,15]$.

The objective of this study was to evaluate the diversity of yeasts found in raw goat milk and goat cheese in a Metropolitan area in South Brazil. The HMA technique was used for confirmation of the potentially pathogenic species previously identified by the conventional technique.

\section{MATERIALS AND METHODS}

\section{Samples of milk and lactic products}

The study was performed with a total of 25 samples, 15 of raw goat milk and 10 of goat creamed cheese from four producers in the Metropolitan region of Porto Alegre during a period of six months. Five mililiters of raw milk from mixtures were aseptically collected in sterile flasks. Samples of cheese were directly collected in the commercial wrappings provided by the producers. All samples were kept under refrigeration and immediately analyzed in the laboratory.

\section{Counting and isolation of yeasts}

Serial decimal dilutions were processed from $1 \mathrm{~mL}$ of goat milk diluted in $9 \mathrm{~mL}$ of sterile distilled water, or $10 \mathrm{~g}$ of cheese samples diluted in $90 \mathrm{~mL}$ of sterile water. Aliquots of $0.1 \mathrm{~mL}$ were collected and inoculated in triplicate on modified YM Petri dishes ( $1 \%$ glucose, $0.3 \%$ malt extract, $0.5 \%$ peptone, 400mg/L chloramphenicol, $2 \%$ agar, $\mathrm{pH} 4.5$ ). After incubation for $3-5$ days at $22-25^{\circ} \mathrm{C}$, the different morphological colonial types were counted, and representatives of each morphotype were isolated and purified in YEPG medium (1\% yeast extract, $2 \%$ glucose, $1 \%$ peptone, $2 \%$ agar). Pure cultures of each strain were maintained on YEPG agar slants covered with sterile mineral oil, and kept in the refrigerator.

\section{Yeast conventional identification}

The isolates were identified by means of phenotypic (morphological and biochemical) criteria [4] and by means of the computer program YEASTCOMPARE (C. Ciriello and M.A.Lachance, Copyright ${ }^{\circledR}$ 1999-2001).

\section{Molecular identification}

Strains identified by the conventional yeast identification methodology as belonging to potentially pathogenic Candida species had their identities confirmed by the heteroduplex mobility assay using the D1/D2 rDNA region [26]. DNA extraction, PCR amplification of the D1/D2 region and HMA assays were performed as described by Ramos et al. (2006) with modifications, aiming the simplification of the method. For heteroduplex formation, 100ng of each PCR-amplified D1/D2 region were combined, followed by addition of $10 \mathrm{X}$ annealing buffer $(1 \mathrm{M} \mathrm{NaCl} ; 100 \mathrm{mM}$ tris, $\mathrm{pH} 7.8 ; 20 \mathrm{mM}$ EDTA). DNA mixtures were heated at $94^{\circ} \mathrm{C}$ for 3 minutes, and rapidly cooled in ice. Homoduplexes and heteroduplexes were separated by electrophoresis on a 5\% polyacrylamide gel at constant $250 \mathrm{~V}$ for $2 \mathrm{~h} 30 \mathrm{~min}$. The bands on the polyacrylamide gels were stained with ethidium bromide, visualized under U.V.-light and scanned. The type strain of each species was used as the positive control for the HMA assay (Candida parapsilosis NRRL Y-12969, Candida tropicalis NRRL Y-12968 and Pichia guilliermondii NRRLY-2075), meaning that if the identification was right, there would be no heteroduplex formation when the PCR products of the milk/cheese strain was mixed with it. The negative controls were chosen based on the shortest genetic distance among the strains. For presumptive $C$. parapsilosis strains, the negative control was the type strain of $C$. tropicalis, meaning 
that heteroduplex should be formed when their PCR products were mixed. The negative control for presumptive $C$. tropicalis and Pichia guilliermondii (anamorph $C$. guilliermondii) was the type strain of C. parapsilosis.

\section{Antifungal susceptibility}

Standard antifungal powders of fluconazole, itraconazole and amphotericin B were obtained from their respective manufactors. Stock solutions were prepared in water (fluconazole) and dimethyl sulphoxide (amphotericin B and itraconazole). Serial twofold dilutions were prepared exactly as outlined in NCCLS document M27-A2 [25]. Final dilutions were made in RPMI 1640 medium buffered to $\mathrm{pH} 7.0$ with $0.165 \mathrm{mmol} \mathrm{l}^{-1}$ morpholinopropanesulphonic acid (MOPS) buffer. The final concentration of the solvent did not exceed $1 \%$ in any well. Aliquots $(100 \mu \mathrm{L})$ of each antifungal agent at $2 \mathrm{X}$ final concentration were dispensed into the wells of plastic microdilution trays and sealed and frozen at $-70^{\circ} \mathrm{C}$ until they were used.

Broth microdilution testing was performed in accordance with the guidelines in NCCLS document M27-A2. The inoculum suspension was prepared by the spectrophotometric method obtaining a final inoculum of $(2.5 \times 1.0) \times 10^{3}$ cells $\mathrm{ml}^{-1}$. Aliquots of $100 \mu \mathrm{L}$ yeast inoculum were added to each well of the microdilution trays. The final concentrations of the antifungal agents were $0.015-16 \mu \mathrm{L}$ for amphotericin $\mathrm{B}$ and itraconazole and $0.031-64 \mu \mathrm{L}$ for fluconazole. The trays were incubated at $35^{\circ} \mathrm{C}$ and MIC endpoints were read after $48 \mathrm{~h}$ of incubation. Drug-free and yeast-free controls were included. Following incubation the MICs of fluconazole and itraconazole were read at the lowest concentration at which a prominent decrease (approximately 50\%) in turbidity relative to the growth control well was observed. Amphotericin B MICs were read as $100 \%$ of growth inhibition. Analytic control was ensured by testing the NCCLS-recommended strains C. krusei ATCC 6258 and $C$. parapsilosis ATCC 22019. The interpretative criteria for susceptibility were those published by NCCLS. Regarding to amphotericin B [9], we established the breakpoint of $\leq 1 \mu \mathrm{L}$ for susceptibility.

\section{Enzymatic profile}

Lypolytic activity was tested in Petri dishes containing $0.67 \%$ Yeast Nitrogen Base (YNB) and $2 \%$ agar plus $0.5 \%$ tween 20 as carbon source. The tested strains were previously inoculated in sterile distilled water for 24 hours in order to exhaust their endogenous carbon resources. Plates were incubated at $22-25^{\circ} \mathrm{C}$ for three weeks. Growth of colonies in the tested medium was considered positive for the production of lipase. Production of caseinase (proteinase) was tested in Petri dishes containing $0.67 \%$ Yeast Nitrogen Base (YNB) plus $0.5 \%$ glucose, $0.5 \%$ casein and $2 \%$ agar ( $\mathrm{pH} 7)$. Plates were incubated for 7 days at $22-25^{\circ} \mathrm{C}$. Evaluation of results was through addition of $\mathrm{HCl} 1 \mathrm{~N}$ over the medium. Result was considered positive when there was the appearance of a transparent halo around the yeast inoculum over a whitish background due to the denaturation of the casein.

\section{RESULTS}

Yeasts were isolated from $59 \%$ of the samples (11 raw milk and 2 cheese samples). Fifty six strains were isolated and identified in the genera Bullera, Candida, Cryptococcus, Debaryomyces, Dekkera, Pichia, Rhodotorula, Sporodiobolus, Trichosporon, Yarrowia and Zygoascus (Table 1). Their counting can also be seen in Table 1. The average total yeast count in raw milk was superior to $2 \log$ UFC. $\mathrm{mL}^{-1}$, while cheese count was superior to $3 \log$ UFC.g ${ }^{-1}$. Lipolytic activity was present in almost $92 \%$ of the isolates, while only $14 \%$ had proteolytic activity (data not shown).

Twelve potentially pathogenic ascomycetic isolates were identified by the conventional yeast identification methodology, and correspond to the species Candida parapsilosis, Candida tropicalis and Pichia guilliermondii (Table 1). All of them had their identities confirmed by the HMA assay (Table 2). None of the strains presumptively belonging to potentially pathogenic species were resistant to the antifungal agents tested (Table 3).

\section{DISCUSSION}

Raw goat milk samples presented counts (1.51 - $4.41 \log$ UFC. $\mathrm{mL}^{-1}$ ) similar to the ones found in raw cow milk collected in the same area [32]. Although there is no yeast count standards established for raw milk, these high numbers can influence the diversity of the mycobiota that will develop in the cheese and other milk derivates. Yeast count in goat creamed cheese was variable but superior to $>3 \log \mathrm{UFC} \mathrm{g}^{-1}$. In Cheddar cheese, counting was between 2 and $7 \log$ UFC. $\mathrm{g}^{-1}[40]$, while mould and yeast counting varied 
Table 1. Conventional identification and counting of yeasts isolated from raw goat milk and goat cheese.

\begin{tabular}{|c|c|c|c|c|c|c|c|c|c|c|c|c|c|c|c|c|}
\hline \multirow[t]{2}{*}{ SPECIES } & \multirow{2}{*}{$\begin{array}{l}\text { NUMBER OF } \\
\text { ISOLATES }\end{array}$} & \multicolumn{11}{|c|}{ RAW MILK (n=15) } & \multirow{2}{*}{$\begin{array}{c}\text { RAW MILK } \\
\text { COUNT } \\
\log \text { UFC/mL }\end{array}$} & \multicolumn{2}{|c|}{$\begin{array}{c}\text { CHEESE } \\
(\mathbf{n}=10)\end{array}$} & \multirow{2}{*}{$\begin{array}{r}\text { CHEESE } \\
\text { COUNT } \\
\log \text { UFC/g }\end{array}$} \\
\hline & & $\mathbf{S} 1^{\mathrm{a}}$ & S2 & S3 & S4 & S5 & S6 & S7 & S8 & S9 & S10 & $\overline{\text { S11 }}$ & & S12 & $\overline{\text { S13 }}$ & \\
\hline Candida aaseri & 1 & & & & & + & & & & & & & 1,51 & & & \\
\hline Candida catenulata & 4 & + & + & & & & & + & & + & & & 2,75 & & + & 3,32 \\
\hline Candida drosophilae-like & 1 & & & & & & & + & & & & & 1,51 & & & \\
\hline Candida glaebosa-like & 1 & & & & + & & & & & & & & 2,49 & & & \\
\hline Candida parapsilosis & 7 & + & & + & + & + & & & + & & & & 2,32 & + & + & 2,14 \\
\hline Candida sake & 1 & & & & & & & & & & + & & 1,51 & & & \\
\hline Candida sorbophila & 1 & & & & & & + & & & & & & 2 & & & \\
\hline Candida tropicalis & 1 & & + & & & & & & & & & & 2,51 & & & \\
\hline Candida zeylanoides & 1 & & & & + & & & & & & & & 1,82 & & & \\
\hline Candida sp. 1 & 1 & + & & & & & & & & & & & 1,51 & & & \\
\hline Candida sp. 2 & 1 & + & & & & & & & & & & & 2 & & & \\
\hline Bullera sp. 1 & 1 & & & & & & & & & & + & & 1,82 & & & \\
\hline Bullera sp. 2 & 1 & & & & & & & & & & + & & 2,36 & & & \\
\hline Cryptococcus curvatus & 2 & & & + & & & & & + & & & & 2,97 & & & \\
\hline Cryptococcus flavus-like & 1 & & & & & & & & + & & & & 1,82 & & & \\
\hline Cryptococcus humicola & 1 & & & & & & & + & & & & & $>2$ & & & \\
\hline Cryptococcus hungaricus & 2 & & & & & & & + & + & & & & 2,94 & & & \\
\hline Cryptococcus hungaricus-like & 1 & & & & & & & & + & & & & 1,82 & & & \\
\hline Cryptococcus terreus-like & 1 & & & & & & & & + & & & & 1,82 & & & \\
\hline Cryptococcus sp. 1 & 1 & & + & & & & & & & & & & 1,82 & & & \\
\hline Cryptococcus sp. 2 & 1 & & & & & & & + & & & & & 2,9 & & & \\
\hline Cryptococcus sp. 3 & 1 & & & & & & & & & + & & & 1,51 & & & \\
\hline Debaryomyces hansenii & 2 & & & & & & & & & + & + & & 1,81 & & & \\
\hline Dekkera anomala & 1 & & & & & & & & & & & + & & & & 1,51 \\
\hline Dekkera bruxellensis & 2 & & & & + & + & & & & & & & 2,39 & & & \\
\hline Pichia guilliermondii & 4 & & & & & + & + & + & & & + & & 2,07 & & & \\
\hline Pichia sp. & 1 & & + & & & & & & & & & & 1,51 & & & \\
\hline Rhodototula glutinis & 1 & & & & & & & & & & & & & + & & 1,51 \\
\hline Rhodototula minuta & 1 & & + & & & & & & & & & & 1,51 & & & \\
\hline Rhodotorula mисilaginosa & 1 & & & & & + & & & & & & & 1,82 & & & \\
\hline Sporidiobolus sp. & 1 & & + & & & & & & & & & & 2,33 & & & \\
\hline Trichosporon ovoides & 1 & & & & & & + & & & & & & 2,56 & & & \\
\hline Tricosporon spp. & 2 & & & & & & & & & & & & & + & + & 1,66 \\
\hline Yarrowia lipolytica & 2 & & & & & & & & & & & & & + & + & 2,52 \\
\hline Zygoascus hellenicus & 1 & & & & & & + & & & & & & 1,82 & & & \\
\hline $\begin{array}{c}\text { TOTAL YEAST COUNT / } \\
\text { SAMPLE } \\
\log \mathrm{UFC} / \mathrm{mL} \text { or } \mathrm{g}\end{array}$ & & 2.81 & 2.95 & 2.79 & 2.61 & 3.36 & 2.66 & 4.41 & 3.67 & 2.94 & 2.66 & 1.51 & & 3.26 & 3.37 & \\
\hline
\end{tabular}


Table 2. Molecular confirmation of the identification of strains that presumptively belong to clinically relevant yeast species by means of HMA of the D1/D2 region of 26S rDNA.

\begin{tabular}{|c|c|c|c|c|}
\hline SPECIES/STRAIN & $\begin{array}{l}\text { SAMPLE } \\
\text { CODE }\end{array}$ & $\begin{array}{l}\text { POSITIVE } \\
\text { CONTROL }^{\mathrm{a}}\end{array}$ & $\begin{array}{l}\text { NEGATIVE } \\
\text { CONTROL }^{\mathrm{b}}\end{array}$ & $\begin{array}{c}\text { HMA } \\
\text { CONFIRMATION }\end{array}$ \\
\hline \multicolumn{5}{|l|}{ Candida parapsilosis } \\
\hline $\mathrm{LC} 04$ & $\mathrm{~S} 1$ & no heteroduplex & heteroduplex & $+^{*}$ \\
\hline LC13 & S3 & no heteroduplex & heteroduplex & + \\
\hline LC20 & $\mathrm{S} 4$ & no heteroduplex & heteroduplex & + \\
\hline $\mathrm{LC} 24$ & S5 & no heteroduplex & heteroduplex & + \\
\hline LC48 & S8 & no heteroduplex & heteroduplex & + \\
\hline LC66 & $\mathrm{S} 12$ & no heteroduplex & heteroduplex & + \\
\hline LC85 & S13 & no heteroduplex & heteroduplex & + \\
\hline \multicolumn{5}{|l|}{ Candida tropicalis } \\
\hline $\mathrm{LC} 12$ & S2 & no heteroduplex & heteroduplex & + \\
\hline \multicolumn{5}{|l|}{ Pichia guilliermondii } \\
\hline $\mathrm{LC} 27$ & S5 & no heteroduplex & heteroduplex & + \\
\hline LC31 & S6 & no heteroduplex & heteroduplex & + \\
\hline LC46 & S7 & no heteroduplex & heteroduplex & + \\
\hline LC78 & S10 & no heteroduplex & heteroduplex & + \\
\hline
\end{tabular}

between 4 and 8 log UFC. $\mathrm{g}^{-1}$ in samples of coalho and butter cheese [14]. Yeast counts in raw milk inferior to $4 \log \mathrm{CFU} / \mathrm{mL}$ may be considered low [15], whereas superior counts may indicate deficiencies in the hygienization, milking and conservation of milk [5].

A high percentage of the isolates presented lipolytic activity (almost 92\%), while only 14\% were proteolytic. The high production of lipase seems to be common in raw milk isolates [32]. Production of extracellular enzymes may alter the organoleptic characteristics of raw milk [26] and, as microorganisms can survive the thermal treatments, they can cause alterations in the texture and flavor of lactic products during the storage [7,37]. On the other hand, the presence of yeasts may be beneficial, contributing to the manufacture of lactic products and certain cheese types through the interaction with start cultures of lactic acid bacteria and the secondary flora composed by bacteria and other fungi [39].

In spite of the low sampling number, samples of raw goat milk presented a great number of distinct species (at least 32), suggesting a great diversity (Table 1). This was also found in raw cow milk samples in the same area [32], and seems to be common in this kind of sample. Samples of goat cheese, on the other hand, presented a low number of distinct species. This apparent low yeast diversity is misleading due to the few samples which allowed yeast isolation (only two samples), but each sample had the same diversity (4 species) as found in raw goat milk samples ( 1 to 6 species per sample).

It is known that the phenotypic characterization of yeasts can lead to errors due to the fact that several species present similarities in their morphologies and biochemical / physiological characteristics used in the conventional identification of yeasts. New molecular techniques are being developed to identify and characterize microorganisms originated from cheese and raw milk [6,8,24]. Recently, Ramos et al. (2006) reported a molecular technique for confirmation of the identification of clinically important yeasts belonging to the genus Candida. This technique is based on the Heteroduplex Mobility Assay (HMA) of the 26S rDNA D1/D2 region. In a simple explanation, when the D1/ D2 PCR products of yeast strains belonging to the same species are mixed, they do not form heteroduplexes in 
Table 3. Antifungal susceptibility thresholds of strains that presumptively belong to clinically relevant yeast species isolated from goat milk and cheese.

\begin{tabular}{|c|c|c|c|}
\hline SPECIES/STRAIN & $\begin{array}{c}\text { FLUCONAZOLE } \\
\text { CIM } \\
\mu \mathrm{g} / \mathrm{mL}\end{array}$ & $\begin{array}{c}\text { ITRACONAZOLE } \\
\text { CIM } \\
\mu \mathrm{g} / \mathrm{mL}\end{array}$ & $\begin{array}{c}\text { AMPHOTERICIN B } \\
\text { CIM } \\
\mu \mathrm{g} / \mathrm{mL}\end{array}$ \\
\hline \multicolumn{4}{|l|}{ Candida parapsilosis } \\
\hline LC04 & 0.5 & 0.03 & 0.03 \\
\hline LC13 & 0.5 & 0.03 & 0.3 \\
\hline LC20 & 0.5 & 0.06 & 0.015 \\
\hline LC24 & 0.5 & 0.06 & 0.015 \\
\hline LC48 & 1 & 0.125 & 0.06 \\
\hline LC66 & 1 & 0.125 & 0.015 \\
\hline LC85 & 4 & 0.125 & 0.015 \\
\hline \multicolumn{4}{|l|}{ Candida tropicalis } \\
\hline $\mathrm{LC} 12$ & 8 & 0.0625 & 0.5 \\
\hline \multicolumn{4}{|l|}{ Pichia guilliermondii } \\
\hline $\mathrm{LC} 27$ & 0.5 & 0.03 & 0.015 \\
\hline LC31 & 1 & 0.125 & 0.015 \\
\hline LC46 & 4 & 0.125 & 0.015 \\
\hline LC78 & 0.5 & 0.03 & 0.06 \\
\hline
\end{tabular}

a polyacrilamide gel electrophoresis. When PCR products of strains belonging to different species are mixed, the heteroduplexes are easily detected. Thus, confirmation of the identification of clinically important yeasts is done by separately mixing their PCR products with the products obtained from the type strain of the presumed species and from the other potentially pathogenic Candida species, followed by polyacrilamide gel electrophoresis.

The most frequent species isolated from raw goat milk were $C$. parapsilosis, Candida catenulata and $P$. guilliermondii (anamorph Candida guilliermondii) (Table 1). C. parapsilosis and P. guilliermondii strains had their identities confirmed by the HMA assay (Table 2). This raises a great concern because these species are considered as potentially pathogenic for humans and other animals [3,29]. Another potentially pathogenic species, C. tropicalis, also confirmed by the HMA assay, was isolated from raw milk (Tables 1 and 2). Six out of 11 milk samples with yeast isolation yielded potentially pathogenic yeasts confirmed by molecular methods, but this was not associated with high total yeast numbers. It would be interesting to verify if the goat herd suffers from mastitis caused by those yeasts. If this is the case, resistance to antifungal agents does not seem to be disseminated, facilitating treatment (Table 3). The other most frequent species in raw goat milk, Candida catenulata, although not considered specially pathogenic, seems to be directly related to cases of mycotic mastitis, and was already isolated from milk from animals with mastitis [1,22,33].

The occurrence of these potentially pathogenic yeasts in milk samples has been already reported [19], but there seems to be no difference between the degrees of contamination of the milk collected from animals with and without mastitis [22]. The isolation of yeasts as $C$. parapsilosis and $C$. tropicalis may be related to treatments with antibiotics in animals with mastitis [21]. Most studies concerning animal mastitis are related to cow, and fungi are not considered primary agents, usually being considered environmental contaminants related to poor hygienic condition of the animal [32]. In cows, mycotic mastitis is predominantly caused by yeasts of the genera Candida, Cryptococcus and Trichosporon [18,34]. Richard et al. (1980) found C. tropicalis and Candida rugosa to be the most common species isolated from infected mammary glands of cows in New York and Iowa. An experi- 
mental study concerning the potential of Candida albicans to cause mastitis in goats proved that there was a sharp fall in milk yield, and $C$. albicans was directly demonstrated in the milk and re-isolated from the milk and udder tissues up to 30th day after inoculation [31].

Yeast species isolated from cheese were identified as $C$. parapsilosis (strains identities confirmed by the HMA assay), C. catenulata, Yarrowia lipolytica, Rhodotorula glutinis and Trichosporon spp. (Tables 1 and 2). C. parapsilosis, C. catenulata and Trichosporon sp. were also found in goat milk samples, and are present in raw milk from different species and in several types of cheese $[11,12,23]$. This suggests that these species may survive the treatments for cheese manufacture and may be spread to the human population, being a question of public health concern.

Rhodotorula glutinis, $R$. mucilaginosa and $R$. minuta, found in goat milk and cheese, are frequently isolated from lactic products, and their presence may be related to environmental contamination during the manufacture of the products $[4,41]$. Only three strains of the genus Trichosporon were isolated. Some species of this genus are described as eventual pathogens of man and animals, and were also isolated from the udders of animals with mastitis $[4,38]$. The occurrence of Trichosporon spp. in lactic products can mean lack of hygiene [42]. In goat milk, concentration and frequency of this genus was low, opposed to what was found in raw cow milk [32].

In order to rapidly confirm the identification of the strains belonging to potentially pathogenic yeast species, a simplified HMA assay was developed. In this simplified assay, the PCR product corresponding to the D1/D2 region of the 26S rDNA of the milk / cheese isolate was mixed with the amplicon of the corresponding type strain (positive control) and with the amplicon of the type strain of another pathogenic Candida species (negative control). This simplified assay was able to confirm the identity of all strains that presumptively belonged to potentially pathogenic Candida species, and may be used each time there is a presumptive non-molecular identification, being able to rapidly confirm or discard this identification.

In summary, the presence of potentially pathogenic yeasts in goat raw milk and creamed cheese collected in South Brazil raises concern. The health of the herd should be evaluated, as well as the potential of spread of these yeasts through goat milk and its derivates. More studies are necessary to evaluate the real significance of the isolation of these clinically relevant yeasts.

\section{REFERÊNCIAS}

1 Aalbaek B., Stenderup J., Jensen H.E., Valbak J., Nylin B. \& Huda A. 1994. Mycotic and algal bovine mastitis in Denmark. Acta Pathologica, Microbiologica et Immunologica. 102: 451-456.

2 Al-Majali A.M. \& Jawabreh S. 2003. Period prevalence and etiology of subclinical mastitis in Awassi sheep in southern Jordan. Small Ruminant Research. 47: 243-248.

3 Barchiesi F., Spreghini E., Tomassetti S., Vittoria A.D., Arzeni D., Manso E. \& Scalise G. 2006. Effects of Caspofungin against Candida guilliermondii and Candida parapsilosis. Antimicrobial Agents and Chemotherapy. 50: 2719-2727.

4 Barnett J.A., Payne R.W. \& Yarrow D. 2000. Yeast, characteristics and identification. Cambridge: Cambridge University Press, 1150p.

5 Brito M.A.V.P., Brito J.R.F., Souza H.M. \& Vargas O.L. 1998. Avaliação da sensibilidade da cultura de leite do tanque para isolamento de agentes contagiosos da mastite bovina. Pesquisa Veterinária Brasileira. 18: 39-44.

6 Callon C., Delbès C., Duthoit F. \& Montel M. C. 2006. Application of SSCP-PCR fingerprinting to profile the yeast community in raw milk Salers cheeses. Systematic and Applied Microbiology. 29: 172-180.

7 Chen L., Daniel R.M. \& Coobear T. 2003. Detection and impact of protease and lipase activities in milk and milk powders. International Dairy Journal. 13: 255-275.

8 Cocolin L., Aggio D., Manzano M., Cantoni C. \& Comi G. 2002. An application of PCR-DGGE analysis to profile the yeast populations in raw milk. International Dairy Journal. 12: 407-411.

9 Collin B., Clancy C.J. \& Nguyen M.H. 1999. Antifungal resistance in non-albicans Candida species. Drug resistance updates. 2: 9-14.

10 Contreras A., Corrales J.A., Sierra D. \& Marco J. 1995. Prevalence and aetiology of non-clinical intramammary infection in Murciano-Granadina goats. Small Ruminant Research. 17: 71-78. 
11 Corbo M.R., Lanciotti R., Albenzio M. \& Sinigaglia M. 2001. Occurrence and characterization of yeasts isolated from milks and dairy products of Apulia region. International Journal of Food Microbiology. 69: 146-152.

12 Costa E.O., Gandra C.R., Pires M.F., Coutinho S.D., Castilho W. \& Teixeira C.M. 1993. Survey of bovine mycotic mastitis in dairy herds in the State of São Paulo, Brazil. Mycopathologia. 124:13-17.

13 Craven H.M. \& Macauley B.J. 1992. Microorganisms in pasteurized milk after refrigerated storage. Australian Journal of Dairy Technology. 47: 38-45.

14 Feitosa T., Borges M.F. \& Nassu R.T. 2003. Pesquisa de Salmonella sp., Listeria sp. e microrganismos indicadores higiênico-sanitários em queijos produzidos no Estado do Rio Grande do Norte. Ciência e Tecnologia Alimentos. 23: 162165.

15 Fleet G.H. 1990. Yeasts in dairy products, A Review. The Journal of applied bacteriology. 68:199-211.

16 Fleet G.H. \& Mian M.A. 1987. The occurrence and growth of yeasts in dairy products. International Journal of Food Microbiology. 4: 145-155.

17 Gardini F., Tofalo R., Belleti N., Iucci L., Suzzi G., Torriani S., Guerzoni M.E. \& Lanciotti R. 2006. Characterization of yeasts of yeasts involved in the ripening of Pecorino Crotonese Cheese. Food Microbiology. 23: 641-648.

18 Jensen H.E., Monteiros A.E. \& Carrasco L. 1996. Caprine Mastitis due to Aspergillosis and Zygomycosis: a Pathological and Immunohistochemical Study. Journal of Comparative Pathology. 114: 183-191.

19 Krukowski H., Lisowski A., Rózanski P. \& Skórka A. 2006. Yeasts and algae isolated from cows with mastitis in the southeastern part of Poland. Polish Journal of Veterinary Sciences. 9: 181-184.

20 Krukowski H. \& Saba L. 2003. Bovine Mycotic Mastitis (A Review). Folia Veteterinaria. 47: 3-7.

21 Krukowski H., Tietze M., Majewski T. \& Rózanski P. 2000. Survey of yeast mastitis in dairy herds of small-type farms in the Lublin region, Poland. Mycopathologia. 150: 5-7.

22 Lagneau P.E., Lebtahi K. \& Swinne D. 1996. Isolation of yeasts from bovine milk in Belgium. Mycopathologia. 135: 99102.

23 Lanciotti R., Chaves-López C., Patrignani F., Paparella A., Guerzone M. E., Serio A. \& Suzzi G. 2004. Effects of milk treatment with dynamic high pressure on microbial populations, and lipolytic and proteolytic profiles of Crescenza cheese. International Journal of Dairy Technology. 57: 19-25.

24 Lopandic K., Zelger S., Bánszky L.K., Eliskases-Lechner F. \& Prillinger H. 2006. Identification of yeasts associeated with milk products using traditional and molecular techniques. Food Microbiology. 23: 341-350.

25 National Committee for Clinical Laboratory Standards. Reference method for broth dilution antifungal susceptibility testing of yeasts; approved method. NCCLS document M27-A2. Wayne, PA: National Committee for Clinical Laboratory Standards, 2002.

26 Ramos J., Rosa C., Carvalho E., Leoncini O. \& Valente P. 2006. Heteroduplex mobility assay of the 26S rDNA D1/D2 region for differentiation of clinically relevant Candida species. Antonie van Leeuwenhoek. 89: 39-44.

27 Richard J.L., MacDonald J.S., Fichtner R.E. \& Anderson A.J. 1980. Identification of yeasts from infected bovine mammary glands and their experimental infectivity in cattle. American Journal of Veterinary Research. 48: 1991-1994.

28 Roostita R. \& Fleet G.H. 1996. Growth of yeasts in milk and associated changes to milk composition. International Journal of Food Microbiology. 31: 205-219.

29 Santos R.C. \& Marin J.M. 2005. Isolation of Candida spp. from mastitic bovine milk in Brazil. Mycopathologia. 159: 251-253.

30 Shena A. \& Siegler L. 1995. Candida krusei isolated from a sporadic case of bovine mastitis. The Canadian Veterinary Journal. 36: 365-365.

31 Singh P., Sood N., Gupta P.P., Jand S.K. \& Banga H.S. 1998. Experimental candidal mastitis in goats: Clinical, haematological, biochemical and sequential pathological studies. Mycopathologia. 140: 89-97.

32 Spanamberg A., Hartfelder C.C., Fuentefria A.M. \& Valente P. 2004. Diversity and enzyme production by yeasts isolated from raw milk in Southern Brazil. Acta Scientiae Veterinaire. 32: 195-199.

33 Spanamberg A., Wünder Jr E.A., Pereira D.I.B., Argenta J., Sanches E.M.C., Valente P., Ferreiro L. 2008. Diversity of yeasts from bovine mastitis in southern Brazil. Revista Iberoamericana de Micología. 25: 154-156.

34 Spanamberg A., Sanches E.M.C., Santurio J. \& Ferreiro L. 2009. Mastite micótica em ruminantes causada por leveduras. Ciência Rural. 39: 282-290.

35 Suzzi G., Shirone M., Martuscelli M., Gatti M., Fornasari M.E. \& Neviani E. 2003. Yeasts associated with Manteca. FEMS Yeast Research. 3: 159-166. 
36 Swinne D., Deka K.E., Assogba A. \& Desmet P. 1997. Identification of yeasts from individual farm tank milk samples in Belgium. Vlaams Diergeneekunding Tijdschrift. 66: 129-130.

37 Vachlu J. \& Kour A. 2006. Yeast lipases: enzyme purification, biochemical properties and gene cloning. Electronic Journal of Biotechnology. 9: 69-75.

38 Victoria C. \& Langoni H. 2006. Occurrence of clinical and subclinical mastitis in dairy herd caused by Trichosporon beigelli. Brazilian Journal of Veterinary Research and Animal Science. 43: 280-282.

39 Viljoen B.C. 2001. The interaction between yeasts and bacteria in dairy environments. International Journal of Food Microbiology. 69: 37-44.

40 Welthagen J.J. \& Viljoen B.C. 1999. The isolation and identification of yeasts obtained during the manufacture and ripening of Cheddar cheese. Food Microbiology. 16: 63-73.

41 Welthagen J.J. \& Viljoen B.C. 1998. Yeast profile in Gouda cheese during processing and ripening. International Journal of Food Microbiology. 41: 185-194.

42 Westall S. \& Filtenborg O. 1998. Spoilage yeasts of decorated soft cheese packet in modified atmosphere. Food Microbiology. 15: 243-249. 